\title{
American Board of Family Medicine Elects New Officers and Board Members
}

\author{
Jane Ireland, $M D$
}

The American Board of Family Medicine (ABFM) is pleased to announce the election of 4 new officers and 4 new board members. The new officers elected at the ABFM's spring board meeting in April are Carlos Roberto Jaén, MD, of San Antonio, Texas, elected as Chair; James Kennedy, MD, of Winter Park, Colorado, elected as Chair Elect; Alan K. David, MD, of Milwaukee, Wisconsin, elected as Treasurer; and Jimmy H. Hara, MD, of Los Angeles, California, elected as Member-atLarge, Executive Committee. In addition, the ABFM welcomes this year's new members to the Board of Directors: Joseph W. Gravel, MD, of North Reading, Massachusetts; Jerry E. Kruse, MD, MSPH, of Springfield, Illinois; Lorna Anne Lynn, MD, of Wynnewood, Pennsylvania; and David E. Soper, MD, of Mt. Pleasant, South Carolina.

\section{The New ABFM Officers}

The new ABFM officers each will serve a 1-year term.

Carlos Roberto Jaén, MD, Chair, is the Chair-

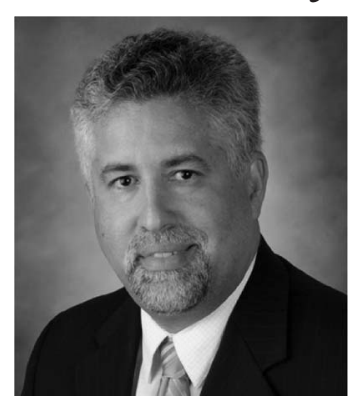

man of the Department of Family and Community Medicine at the University of Texas Health Science Center at San Antonio. He previously was codirector of the Center for Research in Family Medicine and Primary Care and served as chair of the Research Development Committee of the Association of Departments of Family Medicine. He is also an adjunct professor at the University of Texas School of Public Health, San Antonio Regional Campus, and a scholar at the Research to Advance Community Health (ReACH) Center, also in San Antonio. Dr.

Conflict of interest: (JI) is the communications editor for the ABFM.
Jaén will serve the ABFM on the Executive Committee as its Chair.

James Kennedy, MD, Chair-Elect, is a practicing family physician in Winter Park, Colorado, where he started a new advanced idealized micropractice in 2005. He is also the chair of the County Medical Society and the rural health network in his community. In addition, Dr. Kennedy has served as an assistant/associate professor of Family Medicine at the University of Colorado Health Sciences Center since 1994. Dr. Kennedy will serve the ABFM on the Executive Committee, the Bylaws Committee, the Credentials Committee, the Examination Committee, the Audit/Finance Committee, the Communications/Publications Committee, the Maintenance of Certification-Family Physicians (MC-FP) Committee, and the Operations Committee as its Chair.

Alan K. David, MD, Treasurer, is the chairman of

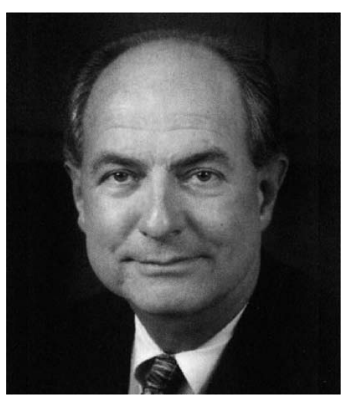
the Department of Family Medicine and associate dean for faculty affairs at the Medical College of Wisconsin. He previously served as the family medicine department chair at the University of Cincinnati and the University of Kentucky. Dr. David currently serves as the chair of the Residency Education Committee for the Association of Departments of Family Medicine. He also served as president and chairman of the Board of Directors of the Wisconsin Academy of Family Physicians. Dr. David will serve the ABFM on the Executive Committee, the Credentials Committee, the 
Examination Committee, the Research \& Development Committee, the Communications/Publications Committee, the Bylaws Committee as its Chair, and the Audit/Finance Committee as its Chair.

Jimmy H. Hara, MD, Member-at-Large, Execu-

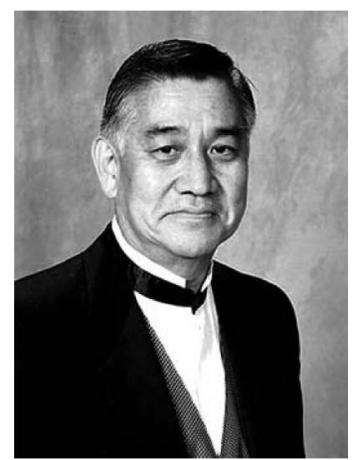

tive Committee, serves as associate dean and professor of Family Medicine at Charles Drew University of Medicine and Science. He previously served as the regional lead physician for Community Benefit for Southern California Kaiser Permanente and is the residency program director emeritus, after serving 25

years as Director for Kaiser Los Angeles. Dr. Hara is also a clinical professor of family medicine at the David Geffen School of Medicine at UCLA. For the past year he has served as Fire Commissioner for the city of Los Angeles. In 2006, he received the American Academy of Family Physician's Nikitas Zervanos National Outstanding Residency Program Director Award and in 2009 received the Physician Humanitarian Award from the Medical Board of California. Dr. Hara will serve the ABFM on the Executive Committee, the Bylaws Committee, the Operations Committee, the Examination Committee, the Audit/Finance Committee, the Research \& Development Committee, the MC-FP Committee, and the Credentials Committee as its Chair.

\section{The ABFM Welcomes 4 New Members to the Board of Directors}

Joseph W. Gravel, Jr, MD, is the chief medical officer

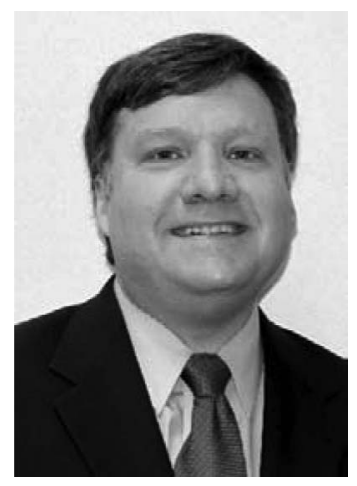

for the Greater Lawrence Family Health Center and the residency program director for the Lawrence Family Medicine Residency. He has been a residency program director for 19 years. He is the immediate past president of the Massachusetts Academy of Family Physicians and a past president of the Association of Family Medicine Residency Directors and the Family Medicine Education Consortium. Dr. Gravel is a professor of family medicine \& community health at the University of Massachusetts Medical School. Dr. Gravel will serve the $\mathrm{ABFM}$ on the Operations Committee and the Examination Committee.

Jerry E. Kruse, MD, MSPH, is a professor in

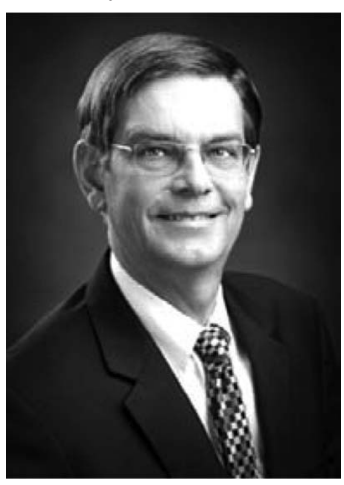

both the Departments of Family \& Community Medicine and Medical Education and is executive associate dean at Southern Illinois University School of Medicine. Before this, Dr. Kruse spent 9 years as the executive director of the Quincy Family Medicine Programs and 19 years on the faculty of the Quincy Family Practice

Residency Program, serving as assistant program director for 9 years and as program director for 12 years. Dr. Kruse will serve the ABFM on the Research and Development Committee and the Communications/Publications Committee.

Lorna Anne Lynn, MD, is the director of prac-

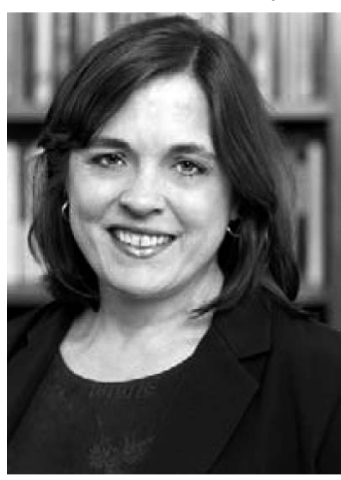

tice assessment development and evaluation and staff administrator for the Conflict of Interest Committees for the American Board of Internal Medicine (ABIM). Before this, she served as the ABIM's director of practice improvement module research for 4 years and as the director of recertification development for 9 years. Dr. Lynn will serve the ABFM on the Examination Committee and the MC-FP Committee.

David E. Soper, MD, is the vice chairman

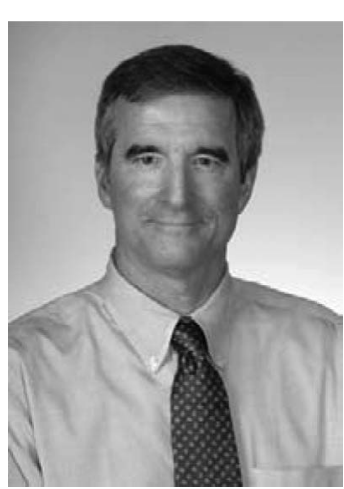
and director of the Division of Academic Specialists in General Obstetrics and Gynecology in the Department of Obstetrics and Gynecology at the Medical University of South Carolina (MUSC). He is also the J. Marion Sims Professor of Obstetrics and 
Gynecology at MUSC. Dr. Soper will serve the ABFM on the Credentials Committee and the Communications/Publications Committee.

The remaining current members of the board are Elizabeth G. Baxley, MD, of Greenville, North Carolina; Diane Beebe, MD, of Jackson, Mississippi; Laura M. Brooks, MD, of Lynch- burg, Virginia; Montgomery Douglas, MD, of Valhalla, New York; Christine C. Matson, MD, of Norfolk, Virginia, David E. Mercer, MD, of Omaha, Nebraska; Marcia J. Nielsen, PhD, of Lawrence, Kansas; Kailie R. Shaw, MD, of Tampa, Florida; and Keith L. Stelter, MD, of Mankato, Minnesota. 